\title{
Kronik Hepatit C Tedavisinde Direkt Etkili Antiviral Ajanların Tedavi Yanıtının Gerçek Yaşam Verileri: Tek Merkez Çalışması
}

\section{The Real-World Outcomes of Virologic Response of Treatment with Direct Acting An- tiviral Agents of Chronic Hepatitis C: Single Center Study}

\section{Özlem Özer Çakır}

Alanya Alaaddin Keykubat Üniversitesi, Tip Fakültesi, Gastroenteroloji ve Hepatoloji Bilim Dalı, Antalya

Yazısma Adresi / Correspondence:
Özlem Özer Çakır
Alanya Alaaddin Keykubat Üniversitesi, Tip Fakültesi, Gastroenteroloji ve Hepatoloji Bilim Dalı, Kestel Yerleşkesi, Alanya, Antalya

T: +902425106135 E-mail: : tansozlem@yahoo.com

Geliş Tarihi / Received : 26.05.2019 Kabul Tarihi / Accepted : 09.08.2019

Orcid :

Özlem Özer Çakır: https://orcid.org/0000-0002-5916-8049

Öz

Amaç Kronik Hepatit C tedavisinde ülkemizde Haziran 2016'dan beri kullanıma giren direkt etkili antiviral ajanların tedavi yanıtlarının gerçek yaşam verilerini sunarak, bu tedavilerin etkinliğini araştırmayı amaçladık. (Sakarya Tip Dergisi 2019, 9(3):455-463)

Gereç ve Temmuz 2017 ile Eylül 2018 tarihleri arasında Kronik Hepatit C hastalı̆̆ı için direkt etkili antiviral ajanlarla tedavi olan hastaların retrospektif olarak tedavi yanıtları Yöntemler incelendi. Hastaların klinik, demografik özellikleri, tedavi sırasındaki yan etkiler, 4. 12. ve 24. hafta HCV RNA seviyeleri hastane veri tabanından kaydedildi.

Bulgular Arașırma popülasyonu (Ombitasvir+Paritaprevir+Ritonavir)+Dasabuvir (OPrD) kullanan 7 hasta (\%36,8) ve (Ombitasvir+Paritaprevir+Ritonavir)+Dasabuvir + Ribavirin (OPrD+rib) kullanan 12 hasta (\%63,2) olmak üzere toplam 19 Kronik Hepatit C hastasından oluştu. Hastaların yaş aralığı 20-69 yıl olup ortalaması 43,8 $\pm 13,6$ yl ve \%57,9'u (n:11) erkek idi. Hastaları \%42,1'inde (n:8) genotip 1a, \%36,8'inde (n:7) genotip 1b ve \%21,1'inde (n:4) genotip 4 idi. OPrD kullanan hastalarda 4 . haftada RNA düzeyi 0 olan hasta oranı $\% 28,6$ ve $<12 \mathrm{IU} / \mathrm{ml}$ 'nin altında olan hasta oranı $\% 42,9$ idi, 12 . ve 24 . haftada hastaların tamamında RNA düzeyi 0 idi (p $<0,001$ ). OPrD+rib kullanan hastalarda 4 . haftada RNA düzeyi 0 olan hasta oranı $\% 58,3$ ve $<12 \mathrm{IU} / \mathrm{ml}$ 'nin altında olan hasta oranı $\% 33,3$ idi, 12 . ve 24 . haftada ise hastaların tamamında RNA düzeyi 0 idi $(\mathrm{p}<0,001)$.

Sonuç Kronik Hepatit C tedavisinde direkt etkili antiviral ajanların kalıcı viral yanıt oranı gerçek yaşam verilerimizde \%100 olup, iyi tolere edilebilen ilaçlardır.

Anahtar Direkt etkili antiviral ajanlar; kronik hepatit C; kalıcı virolojik yanıt; gerçek yaşam verileri

Kelimeler

Abstract

Objective We aimed to investigate the efficacy of the treatment which is a direct acting antiviral agent currently offering real-life data and exists since June 2016 in our country against Chronic Hepatitis C. (Sakarya Med J 2019, 9(3):455-463)

Materials Patients with chronic hepatitis $C$ treated with new direct acting antiviral agents were retrospectively evaluated for sustained virologic response in our university affiliated hospital between and Methods July 2017 and September 2018. Clinical and demographic characteristics of patients, side effects during treatments, 4., 12. and 24th weeks HCV RNA levels were recorded from the hospital database.

Results A total of 19 chronic hepatitis C patients were included in our study ( 7 patients (36.8\%) using (Ombitasvir + Paritaprevir + Ritonavir) + Dasabuvir (OPrD) and 12 patients $(63.2 \%)$ using $($ Ombitasvir + Paritaprevir + Ritonavir $)+$ Dasabuvir + Ribavirin $)(O P r D+$ rib $)$. The age range of the patients was 20-69 years, the mean age of the patients was $43.8 \pm 13.6$ years and $57.9 \%$ of the patients were male (n: 11). The genotypes determined in our patients were, genotype 1a in $42.1 \%(n: 8)$, genotype $1 \mathrm{~b}$ in $36.8 \%$ ( $n: 7)$, and genotype 4 in $21.1 \%$ ( $n: 4)$. Patients treated with OPrD had a RNA level of 0 at week 4 with a rate of $28.6 \%$ and RNA level of $<12 \mathrm{IU} / \mathrm{ml}$ with a rate of $42.9 \%$. All of these patients had HCV RNA level of 0 , at weeks 12 and 24 ( $p<0.001$ ). Patients treated with OPrD rib had a RNA level of 0 at week 4 with a rate of $58.3 \%$ and RNA level of $<12 \mathrm{IU} / \mathrm{ml}$ with a rate of $33.3 \%$. HCV RNA level was 0 in all of the patients at 12 th and 24th weeks in patients treated with $\mathrm{OprD}+\mathrm{rib}(\mathrm{p}<0.001)$

Conclusion Treatment with direct-acting antiviral agents is well tolerated and treatment of chronic hepatitis $C$ with these agents provide sustained virologic response rate is $100 \%$ in our real-world outcomes.

Keywords Direct acting antiviral agents; chronic hepatits C; sustained virologic response; real-world outcomes 


\section{GIIRIŞ}

Hepatit C virüs enfeksiyonu tüm dünyada kronik karaciğer hastalıklarının ana nedenlerinden biridir. Karaciğer hasarı minimal histolojik değişikliklerden, ileri derece fibrozis, siroz ve hepatosellüler karsinoma kadar değişiklik gösterebilir. Tüm dünyada yaklaşık 71 milyon insan kronik hepatit $\mathrm{C}$ enfeksiyonuyla enfektedir. ${ }^{1,2}$ Ülkemizde ise yaklaşık 600-700 bin kişi hepatit C ile enfektedir. ${ }^{3}$ Kronik Hepatit C'nin tedavisinde son zamanlarda yeni tedavi rejimlerinin gündeme gelmesi ile interferonsuz, iyi tolere edilebilen, tedavi yanıt oranı yüksek oral rejimler mevcut hale gelmiştir. Daha iyi tolere edilebilen, daha etkili direkt etkili antiviral ajanlar; sofosbuvir, ledipasvir/ sofosbuvir, simeprevir, daclatasvir, ombitasvir/ paritaprevir/ ritonavir ve dasabuvirdir. Sonuç olarak, kronik hepatit C enfeksiyonu olan hastaların çoğunluğu bu oral ilaçlarla başarılı bir şekilde tedavi edilebilir. ${ }^{4-6}$ Türkiye'de bu ilaçların mevcudiyeti ve sağlık uygulama tebligatı kapsamında geri ödemeye girişi Haziran 2016 yılında olmuştur.

Ülkemizde gerçek yaşam verileri kısıtlı sayıda olup, çalışmamızda direkt antiviral ajanlarla tedavi gören Hepatit C ile kronik enfekte hastalarımızın kalıcı viral yanıt oranlarını araştırmayı amaçladık.

\section{GEREÇ ve YÖNTEMLER}

Alanya Alaaddin Keykubat Üniversitesi Eğitim ve Araştırma hastanesinde Temmuz 2017 ile Eylül 2018 tarihleri arasında Kronik Hepatit C nedeniyle direkt antiviral ajanlarla tedavi gören hastalar retrospektif olarak çalışmamıza dahil edildi. Alanya Alaaddin Keykubat Üniversitesi Etik Kurulu'ndan 29/03/2019 tarihinde 5-16 karar no ile kesitsel tipte tanımlayıcı çalışmamız için onay alındı. Hastalar, ülkemizdeki Sağlık Uygulama Tebliğine göre tedavi endikasyonu konulan ve bu endikasyonlara uyan tedavi rejimlerini alan hastalardı. Hastaların klinik, demografik ve laboratuvar verileri hastane veri tabanından kaydedildi. Hastaların tedavi öncesi bazal, 4. Hafta (tedavi sırasında), 12. hafta (tedavi sonunda) ve 24 . hafta (tedavi bitiminden sonraki 24. hafta)(Kalıcı Viral Yanıt 24) (KVY24) HCV
RNA seviyeleri de kaydedildi. Hastaların HCV RNA seviyelerine göre viral yanıt oranları araştırıldı. Hastaların tedavi sırasındaki raporlanmış yan etkileri de kaydedildi. Sağlık Uygulama Tebliğine göre hastalara verilmiş tedaviler şöyledir; Genotip 1a hastalar için; nonsirotikse (Ombitasvir+Paritaprevir+Ritonavir) +Dasabuvir+Ribavirin ile tedavi süresi toplam 12 hafta, sirotik Genotip 1a (Child A):(Ombitasvir+Paritaprevir+Ritonavir $)+$ Dasabuvir+(Ribavirin) ile toplam tedavi süresi 24 haftadır. Genotip 1b (nonsirotikse):(Ombitasvir+Paritaprevir+Ritonavir)+Dasabuvir ile tedavi süresi toplam 12 haftadır. Genotip 1b (Child A): (Ombitasvir+Paritaprevir+Ritonavir)+Dasabuvir ile tedavi süresi toplam 12 haftadır. Genotip 4 nonsirotikse, (Ombitasvir+Paritaprevir+Ritonavir)+ Ribavirin ile toplam tedavi süresi 12 haftadır, Child A ise (Ombitasvir+Paritaprevir+Ritonavir)+ Ribavirin ile toplam tedavi süresi 12 haftadır. Tedavi deneyimli (daha önce Kronik Hepatit C nedeniyle direkt etkili antiviral ajanlardan başka tedavi almış hastalar) Genotip $1 \mathrm{~b}$ ile enfekte nonsirotik veya Child A hastalarda Ombitasvir+Paritaprevir+Ritonavir)+Dasabuvir ile tedavi süresi toplam 12 haftadır.

İstatistiksel değerlendirme Statistical Package for Social Sciences (SPSS) for Windows 20 (IBM SPSS Inc., Chicago, IL) programı kullanılarak yapıldı. Verilerin normal dağılımı Kolmogorov-Smirnov testi ile değerlendirildi. Normal dağılım sergileyen sayısal değişkenler ortalama \pm standart sapma olarak gösterildi ve tedavi gruplarına göre farklılıkları student T testi ile incelendi. Normal dağılım sergilemeyen sayısal değişkenler ortanca ( $\min$ - max) olarak gösterildi ve tedavi gruplarına göre farklılıkları Mann Whitney $U$ testi ile incelendi. Kategorik değişkenler sayı ve yüzde olarak gösterildi ve tedavi gruplarına göre farklılıkları Ki-kare testi ile değerlendirildi. HCV RNA düzeylerinin izlemlerdeki farklılıkları Friedman testi ile yapıldı. İstatistiksel analizlerde $\mathrm{p}<0.05\left(^{*}\right)$ değeri anlamlı olarak kabul edildi.

\section{BULGULAR}

Araştırma popülasyonu Ombitasvir+Paritaprevir+Ritona- 
vir)+Dasabuvir (OPrD) kullanan 7 hasta $(\% 36,8)$ ve Ombitasvir+Paritaprevir+Ritonavir) + Dasabuvir+Ribavirin (OPrD+rib) kullanan 12 hasta $(\% 63,2)$ olmak üzeretoplam 19 Kronik Hepatit C hastasından oluşmaktadır. Hastaların yaş aralığı 20-69 yıl olup ortalaması 43,8土13,6 yıl ve \%57,9’u (n:11) erkek idi. Hastaların büyük çoğunluğu yüksek lisans $(\% 42,1, \mathrm{n}: 8)$ ve lisans $(\% 31,6 ; \mathrm{n}: 6)$ mezunu idi. Hastaların body mass index (BMI) ortalamaları $24,5 \pm 4,3$ kg/m2 idi. Hastaların \%15,8'inde (n:3) komorbidite mevcuttu (hipertansiyon(HT) n:2, diyabetes mellitus (DM) n:1). Sigara kullananların oranı \%36,8 (n:7), alkol kullananların oranı \%5,3 (n:1), uyuşturu madde kullanım öyküsü olanların oranı \%10,5 (n:2) idi. Sirotik olan hasta oranı \%10,5 (n:2) idi ve bu hastaların tamamı Child-Turcot Pugh A idi. Hastaların 16'sının karaciğer biyopsisi mevcuttu ve hepsi fibrozis 3 idi. Diğer hastalardan iki tanesi sirotik olduğu için, bir tanesi de daha önce tedavi deneyimli olduğu için karaciğer biyopsisi alınmamıştı.

OPrD kullanan hastalarda OPrD+rib kullananlara kıyasla ortalama yaş yüksek saptandı $(51,7 \pm 14,6$ vs $39,2 \pm 11,2$; $\mathrm{p}=0,050)$. Diğer demografik özellikler anlamlı farklılık göstermedi (Tablo 1).

Hastaların laboratuvar bulguları Tablo 2'de gösterildi. OPrD ve OPrD+rib kullanan hastalarda laboratuvar bulguları anlamlı farklılık göstermedi.

Hastaların \%89,5’i (n:17) 0 yıldır HCV (yeni tanı), \%5,3’ü (n:1) 2 yıldır, \%5,3’ü (n:1) 7 yıldır HCV enfeksiyonu has- tası idi. Hastaların \%94,7'sinde (n:18) tedavi naif idi, 1 hastanın önceden Peginterferon+Ribavirin tedavisi aldığ 1 belirlendi. Hastaların \%42,1'inde (n:8) genotip 1a, $\% 36,8$ 'inde (n:7) genotip $1 \mathrm{~b}$ ve $\% 21,1$ 'inde (n:4) genotip 4 idi. Hastaların bazal HCV RNA düzeyi 365-4371186 IU/ $\mathrm{ml}$ aralığında olup ortancası $366154 \mathrm{IU} / \mathrm{ml}$ idi. Hastaların tamamında relaps saptanmadı, yan etki saptanan 1 hasta $(\% 5,3)$ belirlendi. Yan etkinin uykusuzluk olduğu izlendi. Tedavi gruplarına göre hastaların klinik özellikleri anlamlı farklılık göstermedi (Tablo 3).

İzlem sürelerine göre HCV RNA düzeyleri Tablo 4’te gösterildi. Tüm popülasyonda hastaların tamamında bazalde HCV RNA düzeyi > 12 IU/ml'nin üzerinde idi, 4. haftada RNA düzeyi 0 olan hasta oranı $\% 47,4$ ve $<12$ 'nin altında olan hasta oran $1 \% 36,8 \mathrm{idi}, 12$. ve 24 . haftada hastaların tamamında RNA düzeyi $0 \mathrm{IU} / \mathrm{ml}$ idi $(\mathrm{p}<0,001)$. OPrD kullanan hastalarda 4 . haftada RNA düzeyi 0 olan hasta oranı \%28,6 ve <12'nin altında olan hasta oranı $\% 42,9$ idi, 12. ve 24. haftada hastaların tamamında RNA düzeyi 0 idi ( $\mathrm{p}<0,001)$. OPrD+rib kullanan hastalarda 4. haftada RNA düzeyi 0 olan hasta oranı $\% 58,3$ ve $<12$ 'nin altında olan hasta oranı \%33,3 idi, 12 . ve 24 . haftada hastaların tamamında RNA düzeyi 0 idi $(\mathrm{p}<0,001)$. Hastaların tamamında kalıcı viral yanıt oranı tedavi bitiminden sonraki 24. haftada (KVY 24) \%100 olarak tespit edildi. 
Sakarya Tip Dergisi 2019;9(3):455-463

ÇAKIR, Kronik Hepatit C ve Yeni Tedaviler

\begin{tabular}{|c|c|c|c|c|}
\hline \multirow[b]{2}{*}{ Değişkenler } & \multirow{2}{*}{$\begin{array}{l}\text { Total } \\
n=19\end{array}$} & \multicolumn{2}{|c|}{ Tedavi } & \multirow[b]{2}{*}{$\mathrm{P}$} \\
\hline & & $\begin{array}{c}\text { OPrD } \\
n=7\end{array}$ & $\begin{array}{c}\text { OPrD+rib } \\
n=12\end{array}$ & \\
\hline Yaş & $43,8 \pm 13,6$ & $51,7 \pm 14,6$ & $39,2 \pm 11,2$ & $0,050^{*}$ \\
\hline \multicolumn{5}{|l|}{ Cinsiyet } \\
\hline 1 & $8(42,1)$ & $5(71,4)$ & $3(25,0)$ & \multirow{2}{*}{0,135} \\
\hline 2 & $11(57,9)$ & $2(28,6)$ & $9(75,0)$ & \\
\hline \multicolumn{5}{|l|}{ Eğitim } \\
\hline Okuryazar Değil & $1(5,3)$ & $1(14,3)$ & - & \multirow{5}{*}{0,253} \\
\hline İlköğretim & $1(5,3)$ & $1(14,3)$ & - & \\
\hline Lise & $3(15,8)$ & - & $3(25,0)$ & \\
\hline Lisans & $6(31,6)$ & $2(28,6)$ & $4(33,3)$ & \\
\hline Yüksek lisans & $8(42,1)$ & $3(42,9)$ & $5(41,7)$ & \\
\hline $\mathrm{BMI}\left(\mathrm{kg} / \mathrm{m}^{2}\right)$ & $24,5 \pm 4,3$ & $26,9 \pm 5,2$ & $23,1 \pm 3,1$ & 0,062 \\
\hline \multicolumn{5}{|l|}{ Komorbidiete } \\
\hline Yok & $16(84,2)$ & $4(57,1)$ & $12(100,0)$ & \multirow{2}{*}{0,069} \\
\hline Var & $3(15,8)$ & $3(42,9)$ & - & \\
\hline HT & $2(10,5)$ & $2(28,6)$ & - & 0,237 \\
\hline $\mathrm{DM}$ & $1(5,3)$ & $1(14,3)$ & - & 0,779 \\
\hline \multicolumn{5}{|l|}{ Sigara } \\
\hline Hayır & $12(63,2)$ & $6(85,7)$ & $6(50,0)$ & \multirow{2}{*}{0,287} \\
\hline Evet & $7(36,8)$ & $1(14,3)$ & $6(50,0)$ & \\
\hline \multicolumn{5}{|l|}{ Alkol } \\
\hline Hayır & $18(94,7)$ & $7(100,0)$ & $11(91,7)$ & \multirow{2}{*}{0,999} \\
\hline Evet & $1(5,3)$ & - & $1(8,3)$ & \\
\hline \multicolumn{5}{|c|}{ Uyuşturucu Madde } \\
\hline Hayır & $17(89,5)$ & $7(100,0)$ & $10(83,3)$ & \multirow{2}{*}{0,714} \\
\hline Evet & $2(10,5)$ & - & $2(16,7)$ & \\
\hline \multicolumn{5}{|l|}{ Sirotik } \\
\hline Hayır & $17(89,5)$ & $5(71,4)$ & $12(100,0)$ & \multirow{2}{*}{0,237} \\
\hline Evet & $2(10,5)$ & $2(28,6)$ & - & \\
\hline CTP A & $2(10,5)$ & $2(28,6)$ & - & 0,237 \\
\hline \multicolumn{5}{|c|}{$\begin{array}{l}\text { Normal dağılım gösterenler ortalama } \pm \text { standart sapma olarak gösterildi. } \\
\text { Kategorik değișkenler sayı ve yüzde olarak belirtildi. } \\
\text { ×p<0,05 istatistiksel anlamlılık göstermektedir. } \\
\text { OPrD: (Ombitasvir+Paritaprevir+Ritonavir)+Dasabuvir, OPrD+rib: Ombitasvir+Paritaprevir+Ritonavir)+Dasabuvir + Ribavirin, BMI: Body mass index, HT: } \\
\text { Hipertansiyon, DM: Diyabetes mellitus, CTP A: Chil-Turcot-Pugh A }\end{array}$} \\
\hline
\end{tabular}


Sakarya Tip Dergisi 2019;9(3):455-463

ÇAKIR, Kronik Hepatit C ve Yeni Tedaviler

\begin{tabular}{|c|c|c|c|c|}
\hline \multirow[b]{2}{*}{ Değişkenler } & \multirow{2}{*}{$\begin{array}{l}\text { Total } \\
\mathrm{n}=19\end{array}$} & \multicolumn{2}{|c|}{ Tedavi } & \multirow[b]{2}{*}{$\mathrm{P}$} \\
\hline & & $\begin{array}{c}\mathrm{OPrD} \\
\mathrm{n}=7\end{array}$ & $\begin{array}{c}\text { OPrD+rib } \\
n=12\end{array}$ & \\
\hline $\mathrm{Hb}(\mathrm{g} / \mathrm{dl})$ & $14 \pm 1,5$ & $13,5 \pm 2$ & $14,3 \pm 1,1$ & 0,300 \\
\hline AST (U/L) & $45(14-89)$ & $45(14-89)$ & $42,5(18-81)$ & 0,711 \\
\hline $\operatorname{ALT}(\mathrm{U} / \mathrm{L})$ & $32(15-147)$ & $32(15-147)$ & $35,5(19-75)$ & 0,536 \\
\hline GGT (U/L) & $37,9 \pm 7,8$ & $37,6 \pm 9,5$ & $38,1 \pm 7,1$ & 0,895 \\
\hline $\mathrm{Alb}(\mathrm{g} / \mathrm{dl})$ & $4,0 \pm 0,3$ & $3,9 \pm 0,4$ & $4,0 \pm 0,2$ & 0,607 \\
\hline Cre (mg/dl) & $0,8 \pm 0,1$ & $0,8 \pm 0,1$ & $0,8 \pm 0,1$ & 0,505 \\
\hline Nötrofil sayısı (/ml) & $3,5(1,5-7,7)$ & $3,5(1,5-7,7)$ & $3,5(2,8-5)$ & 0,902 \\
\hline Lenfosit sayısı $(/ \mathrm{ml})$ & $2,7(1,3-4)$ & $2,5(1,3-3,9)$ & $2,7(1,3-4)$ & 0,837 \\
\hline \multicolumn{5}{|c|}{$\begin{array}{l}\text { Normal dağılım gösterenler ortalama } \pm \text { standart sapma olarak gösterildi. } \\
\text { Normal dağılım, göstermeyenler median (min-max) olarak gösterildi. } \\
\text { ^p<0,05 istatistiksel anlamlılık göstermektedir. } \\
\text { OPrD: (Ombitasvir+Paritaprevir+Ritonavir)+Dasabuvir, OPrD+rib: Ombitasvir+Paritaprevir+Ritonavir)+Dasabuvir + Ribavirin, Hb: Hemoglobin, AST: } \\
\text { Aspartat aminotransferaz, ALT: Alanin aminotransferaz, GGT: Gama glutamil transferaz, Alb: Albumin, Cre: Kreatinin }\end{array}$} \\
\hline
\end{tabular}


Sakarya Tip Dergisi 2019;9(3):455-463

ÇAKIR, Kronik Hepatit C ve Yeni Tedaviler

Tablo 3. Kronik Hepatit C nedeniyle direk etkili antiviral ajanlarla tedavi olan hastaların klinik bulguları

\begin{tabular}{|c|c|c|c|c|}
\hline \multirow[b]{2}{*}{ Değişkenler } & \multirow{2}{*}{$\begin{array}{l}\text { Total } \\
n=19\end{array}$} & \multicolumn{2}{|c|}{ Tedavi } & \multirow[b]{2}{*}{$\mathrm{P}$} \\
\hline & & $\begin{array}{c}\mathrm{OPrD} \\
\mathrm{n}=7\end{array}$ & $\begin{array}{c}\text { OPrD+rib } \\
n=12\end{array}$ & \\
\hline \multicolumn{5}{|l|}{ Hastalık süresi (yıl) } \\
\hline $0($ yeni $\tan 1)$ & $17(89,5)$ & $6(85,7)$ & $11(91,7)$ & \multirow{2}{*}{0,623} \\
\hline 2 & $1(5,3)$ & - & $1(8,3)$ & \\
\hline 7 & $1(5,3)$ & $1(14,3)$ & - & \\
\hline \multicolumn{5}{|l|}{ Kaçyıldır HCV } \\
\hline Yeni tanı & $17(89,5)$ & $6(85,7)$ & $11(91,7)$ & \multirow{2}{*}{0,999} \\
\hline$>1$ Yll & $2(10,5)$ & $1(14,3)$ & $1(8,3)$ & \\
\hline \multicolumn{5}{|l|}{ Tedavi Naif } \\
\hline Evet & $18(94,7)$ & $6(85,7)$ & $12(100,0)$ & \multirow{2}{*}{0,779} \\
\hline Hayır & $1(5,3)$ & $1(14,3)$ & - & \\
\hline \multicolumn{5}{|l|}{ Önceki HCV Tedavisi } \\
\hline Peginterferon+Ribavirin & $1(100,0)$ & $1(100,0)$ & - & - \\
\hline \multicolumn{5}{|l|}{ Genotip } \\
\hline 1a & $8(42,1)$ & - & $8(66,7)$ & \multirow{3}{*}{$<0,001^{*}$} \\
\hline $1 \mathrm{~b}$ & $7(36,8)$ & $7(100)$ & - & \\
\hline 4 & $4(21,1)$ & - & $4(33,3)$ & \\
\hline \multirow{2}{*}{ HCV RNA (IU/ml) } & 366154 & 275898 & 368345,5 & \multirow{2}{*}{0,773} \\
\hline & $(365-4371186)$ & $(219022-2798611)$ & $(365-4371186)$ & \\
\hline \multicolumn{5}{|l|}{ 4. hafta HCVRNA } \\
\hline 0 & 9 & 2 & 7 & \multirow{5}{*}{$?$} \\
\hline$<12$ & 7 & 3 & 4 & \\
\hline 62 & 1 & 1 & 0 & \\
\hline 69 & 1 & 0 & 1 & \\
\hline 89 & 1 & 1 & 0 & \\
\hline \multicolumn{5}{|l|}{ 4. hafta } \\
\hline 0 & $9(47,4)$ & $2(28,6)$ & $7(58,3)$ & \multirow{3}{*}{0,476} \\
\hline$<12$ & $7(36,8)$ & $3(42,9)$ & $4(33,3)$ & \\
\hline $62+$ & $3(15,8)$ & $2(28,6)$ & $1(8,3)$ & \\
\hline 12. hafta HCVRNA & $19(100,0)$ & $7(100,0)$ & $12(100,0)$ & - \\
\hline \multicolumn{5}{|l|}{0} \\
\hline 24. hafta HCVRNA & $19(100,0)$ & $7(100,0)$ & $12(100,0)$ & - \\
\hline \multicolumn{5}{|l|}{0} \\
\hline \multicolumn{5}{|l|}{ Relaps } \\
\hline Var & - & - & - & \multirow{2}{*}{ - } \\
\hline Yok & $19(100,0)$ & $7(100,0)$ & $12(100,0)$ & \\
\hline \multicolumn{5}{|l|}{ Yan Etki } \\
\hline Var & $1(5,3)$ & $1(14,3)$ & - & \multirow{2}{*}{0,779} \\
\hline Yok & $18(94,7)$ & $6(85,7)$ & $12(100,0)$ & \\
\hline Tedavi & & & & \\
\hline OPrD & $7(36,8)$ & $7(100,0)$ & - & \\
\hline $\mathrm{OPrD}+\mathrm{rib}$ & $12(63,2)$ & - & $12(100,0)$ & - \\
\hline $\begin{array}{l}\text { Normal dağı̆lım gösterenler or } \\
\text { Normal dağılım, göstermeyenl } \\
\text { Kategorik değişkenler sayı ve y } \\
\text { ‘p }<0,05 \text { istatistiksel anlamllı } \\
\text { OPrD: (Ombitasvir+Paritapre }\end{array}$ & $\begin{array}{l}\text { lart sapma olarak gö } \\
\text { n-max) olarak göste } \\
\text { lirtildi. } \\
\text { r. } \\
\text { +Dasabuvir, OPrD+ }\end{array}$ & ritanrevir+Bitonay & ivirin, & \\
\hline
\end{tabular}


Sakarya Tip Dergisi 2019;9(3):455-463

ÇAKIR, Kronik Hepatit C ve Yeni Tedaviler

\begin{tabular}{|c|c|c|c|c|c|c|}
\hline Grup & $\begin{array}{l}\text { HCV RNA (IU/ } \\
\text { ml) }\end{array}$ & Bazal & 4.hafta & 12.hafta & 24.hafta & $\mathrm{P}$ \\
\hline \multirow{3}{*}{$\begin{array}{l}\text { Total } \\
\mathrm{n}=19\end{array}$} & 0 & - & $9(47,4)$ & $19(100,0)$ & $19(100,0)$ & \multirow{3}{*}{$<0,001^{*}$} \\
\hline & $<12$ & - & $7(36,8)$ & - & - & \\
\hline & $>12$ & $19(100,0)$ & $3(15,8)$ & - & - & \\
\hline \multirow{3}{*}{$\begin{array}{l}\mathrm{OPrD} \\
\mathrm{n}=7\end{array}$} & 0 & - & $2(28,6)$ & $7(100,0)$ & $7(100,0)$ & \multirow{3}{*}{$<0,001^{*}$} \\
\hline & $<12$ & - & $3(42,9)$ & - & - & \\
\hline & $>12$ & $7(100,0)$ & $2(28,6)$ & - & - & \\
\hline \multirow{3}{*}{$\begin{array}{l}\text { OPrD+rib } \\
\mathrm{n}=12\end{array}$} & 0 & - & $7(58,3)$ & $12(100,0)$ & $12(100,0)$ & \multirow{3}{*}{$<0,001^{*}$} \\
\hline & $<12$ & - & $4(33,3)$ & - & - & \\
\hline & $>12$ & $12(100,0)$ & $1(8,3)$ & - & - & \\
\hline \multicolumn{7}{|c|}{$\begin{array}{l}\text { Kategorik değișkenler sayı ve yüzde olarak belirtildi. } \\
{ }_{*}^{*}<0,05 \text { istatistiksel anlamlllı göstermektedir. }\end{array}$} \\
\hline
\end{tabular}

\section{TARTIŞMA}

Genotip 1 ve 4 ile enfekte kronik hepatit $C$ hastalarında Ombitasvir/paritaprevir/ritonavir \pm dasabuvir \pm ribavirin tedavisinin iyi tolere edilebilen ve yüksek etkinliğe sahip olduğu klinik çalışmalarda gösterilmiştir. ${ }^{7-10}$

Çin'de gerçek yaşam verilerine göre yapılmış bir çalışmada; genotip 1 ile enfekte kronik hepatit $\mathrm{C}$ hastalarında Ombitasvir dasabuvir kombine tedavisinin iyi tolere edilebilirliği ve güvenlirliği gösterilmiştir. Bununla birlikte aynı çalışmada (Kalıcı Viral Yanıt 12) KVY12 oranı \%100 olarak bulunmuştur. $^{8}$

Yapılan bir çalışmada; genotip 1b ile enfekte Kronik Hepatit $\mathrm{C}$ hastalarında tedavi naif ve yanıtsız nonsirotik hastaların Ombitasvir + Paritaprevir + ritonavir (OPr) ile KVY12 oranları sırasılla \%95,2 ile \%90 bulunmuştur. Aynı çalışmada tedavi naif ve tedavi deneyimli sirozlu hastalarda KVY12 oranları sırasıyla \%97,9 ile \%96,2 saptanmıştır.9 Bizim çalışmamız genotip $1 \mathrm{~b}$ ile enfekte kronik hepatit $\mathrm{C}$ hastalarımızda OPrD ile 12 hafta tedavi ile kalıcı viral yanit 24 (KVY24) oranı \%100 olarak tespit edildi. Genotip 1a ve genotip 4 hastalarımızda da OPrD+rib ile 12 hafta tedavi ile KVY24 oranı \%100 olarak tespit edildi. Çalışmamızda direkt etkili antiviral ajanlarla tedavinin tolerebili- tesinin ve güvenliğinin iyi olduğunu gözledik. Bir hastada gözlediğimiz yan etki uykusuzluk idi. Bunun dişında yan etki gözlemlemedik.

Geniş çaplı bir çalışmada genotip 1a $(\mathrm{n}=732$; \%19), genotip $1 \mathrm{~b}(\mathrm{n}=2619 ; \% 69)$ ve genotip $4(\mathrm{n}=457$; \%12) ile enfekte olan hastaların direkt etkili antiviral ajanlarla yapılan tedavilerinde KVY12 oranları sirasıly \%93, \%97 ve \%94 olarak gösterilmiştir. ${ }^{11}$ Başka bir çalışmada ise genotip $1 b$ ile enfekte hastalarda direkt etkili antiviral ajanlarla tedavinin KVY12 oranı \%99,1 ve yan etki oranı \%2,7 olarak saptanmıştır. Çok merkezli yapılan bu çalışmada, genotip 1 hastalarında OPr ile tedavide KVY oranı \%97,6 olarak tespit edilmiştir. ${ }^{12}$ Japonya'da yapılan bir çalışmada ise, direkt etkili antiviral ajanlarla tedavi olan genotip 1 hastalar için KVY24 oranı \%96,6 olarak bulunmuştur. ${ }^{13}$

Türkiye'den şimdiye kadar bir çalışma yapılmış olup, Sivas'tan yapılan bu çalışmada kronik hepatit $C$ ile enfekte genotip 1 hastalarda toplamda KVY oranı \%96,4 olup, tedavi kollarında OPrD \pm rib ile tedavide KVY oranı \%98,2 iken sofosbuvir+ledipasvir \pm rib ile tedavide ise KVY oranı \%96 olarak saptanmıştır'14. Bu çalışmada hastalarda en sık görülen yan etkiler; 18 (\% 22.2) kaşınt1, 17 yorgunluk (\% $21)$ ve 16 (\% 19.8) baş ağrısı olarak tespit edilmiştir. ${ }^{14}$ 
Sonuç olarak; kronik hepatit C tedavisinde direkt etkili antiviral ajanlar bir çığır açmıştır. Yakın zamanda kullanılmaya başlanılan bu ilaçların yüksek etkinlik ve iyi tolere edilebilirliği çalışmalarla gösterilmiştir. Uzun dönem takipler sonrası relaps olup olmayacağını bize zaman gösterecektir. Bizim çalışmamız ile genotip 1a, genotip $1 \mathrm{~b}$ ve genotip 4 hastalarımızda direkt etkili antiviral rejimlerle KVY24 oranını \%100 olarak tespit ettik. Direkt etkili antiviral ajanların kronik hepatit $\mathrm{C}$ tedavisinde güvenli, iyi tolere edilen ve yüksek etkinliğe sahip olduğunu görmekteyiz. 
Sakarya Tip Dergisi 2019;9(3):455-463

ÇAKIR, Kronik Hepatit C ve Yeni Tedaviler

\section{Kaynaklar}

1. Polaris Observatory HCV Collaborators. Global prevalence and genotype distribution of hepatitis C virus infection in 2015: a modelling study. Lancet Gastroenterol Hepatol 2017;2:161-176.

2. European Union $\mathrm{HCV}$ Collaborators. Hepatitis $C$ virus prevalence and level of intervention required to achieve the WHO targets for elimination in the European Union by 2030: a modelling study. Lancet Gastroenterol Hepatol 2017;2:325-336.

3. Tözün N. "HCV infeksiyonunun Türkiye açısından önemi" Epidemiyoloji ve projeler. In: Çakaloğlu Y, ed. Hepatit C Güncelleme Toplantısı (11-13 Ocak 2008, İstanbul) Konușma Metinleri. İstanbul: Türk Karaciğer Araşttrmaları Derneği, 2008:1-3.

4. Arase Y, Kobayashi M, Suzuki F, Suzuki Y, Kawamura Y, Akuta N, et al. Effect of type 2 diabetes on risk for malignancies includes hepatocellular carcinoma in chronic hepatitis $C$. Hepatology 2013;57:964-973.

5. van der Meer AJ, Veldt BJ, Feld JJ, Wedemeyer H, Dufour JF, Lammert F, et al. Association between sustained virological response and all-cause mortality among patients with chronic hepatitis $C$ and advanced hepatic fibrosis. JAMA 2012;308:2584-2593.

6. EASL European Association for the Study of the Liver. EASL Recommendations on Treatment of Hepatitis C 2018. J Hepatol 2019;69(2):461-511.

7. Falcão F, Lopes C, Viegas E, Perez R, Aldir I, Farinha H, et al. Experience of a Portuguese Center: Effectiveness of Direct-Acting Antiviral Therapy for Hepatitis C. Acta Med Port. 2019 Mar 29;32(3):189-194

8. Jie YS, Yuan J, Zhang XH, Guan YJ, Zhao ZX, Chong YT, et al. Real-world study of paritaprevir/ritonavir-ombitasvir combined with dasabuvir for the treatment of chronic hepatitis $C$ 16 genotype infection in China. Zhonghua Gan Zang Bing Za Zhi. 2019 Feb 20;27(2):123127.
9. Lawitz E, Makara M, Akarca US, Thuluvath PJ, Preotescu LL, Varunok P, et al. Efficacy and Safety of Ombitasvir, Paritaprevir, and Ritonavir in an Open-Label Study of Patients With Genotype $1 b$ Chronic Hepatitis C Virus Infection With and Without Cirrhosis. Gastroenterology. 2015 Oct;149(4):971-980.

10. Ferenci P, Bourgeois S, Buggisch P, Norris S, Curescu M, Larrey D, et al. Real-world safety and effectiveness of ombitasvir/paritaprevir/ritonavir \pm dasabuvir \pm ribavirin in hepatitis $C$ virus genotype 1-and 4-infected patients with diverse comorbidities and comedications: A pooled analysis of post-marketing observational studies from 13 countries. J Viral Hepat. 2019 Feb 10. doi: 10.1111/jvh.13080. [Epub ahead of print].

11. Pessoa MG, Ramalho-Madruga JV, Alves K, Nunes EP, Cheinquer H, Brandão-Mello CE, et al. Efficacy and Safety of Ombitasvir/Paritaprevir/Ritonavir and Dasabuvir \pm Ribavirin for HCV in Brazilian Adults with Advanced Fibrosis. Ann Hepatol. 2018 Oct 16;17(6):959-968.

12. Itokawa N, Atsukawa M, Tsubota A, Ikegami T, Shimada $N$, Kato $K$, et al. Efficacy of direct-acting antiviral treatment in patients with compensated liver cirrhosis: A multicenter study. Hepatol Res. 2019 Feb;49(2):125-135.

13. Miyasaka A, Yoshida Y, Yoshida T, Murakami A, Abe K, Ohuchi K, et al. The Real-world Efficacy and Safety of Ombitasvir/Paritaprevir/Ritonavir for Hepatitis C Genotype 1. Intern Med. 2018 Oct 1;57(19):2807-2812.

14. E Cakmak. Türkiye'de kronik Hepatit C Genotip 1 hastalarinda direkt-etkili oral antiviral tedavinin gerçek yașamda etkinliği ve güvenliği. Cumhuriyet Medical Journal 2018; 40(1): 56-64. 